概 論*

九州大学農学部 田 中 浩 雄

\title{
An Introduction to Fundamentals and Applications in Wet-end Operation
}

Hiroo Tanaka

Faculty of Agriculture, Kyushu University

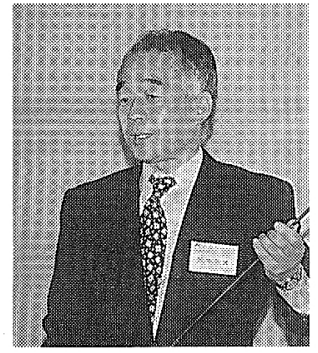

The occurence of charges on solid surfaces and the properties of electrical double layer were explained first, and some kinetic aspects on polymer additives in the wet-end were described.

Under turburent flow conditions the adsorption of polymers on fibers and fillers is very rapid occuring in less than 1 second. The adsorbed polymers will reconform to a less expanded configuration which attains equilibrium state within 2-3 minutes. The reconformation process influences the flocculation efficiency of the adsorbed polymer. When the flocs are destroyed by the turburence, the retained polymers can transfer between fibers and fillers, and the polymer chains can also be cleaved. The penetration of adsorbed polymers into fiber pores occurs very slowly.

It is possible that both the retention and the formation can be improved simultaneously, though the two are usually antinomic phenomena. But most of them are dependent on an ability of engineers at the paper mills.

\section{1.はじめに}

ウェットエンド技術の基礎を理解し，これを上手に 応用すれば，1）紙の諸性質を向上させ，2）製紙の生 産性・経済性も向上させることができる。これは最終 の目標である。今でも，ウェットエンドの技術は種々 の有益性を発揮しているが, 理想の達成にはまだ解決 すべき課題が多い。

紙は周知のように植物繊維などの原料を網で漉し, 乾燥させたシート状の物質である。針葉樹パルプが豊 富な時代には，紙の強度も不透明度も容易に得られた。

*第 4 回製紙技術セミナ一講演
当時は酸性抄紙が主流であり，硫酸バンド（Alum） がウェットエンド助剤として十分に機能した。しかも， マシンは低速であり，ウェットエンド技術はさして重 要ではなかった。

製紙に扮ける近年の動向として,

1) 広葉樹パルプと二次繊維の増加

2) 嘪料の増配

3）抄紙 $\mathrm{pH}$ の上昇と中性（アルカリ）抄紙への移 行

4）マシンの高速化に伴う high shearによる歩留 まりの低下ならびに高濾水性の確保

5) Twin-wire former の增加

6）白水系のクローズド化による溶解成分や an- 
ionic trash の蓄積

などを挙げることができる。

例えば，紙の印刷適性や不透明性を向上させるため に壃料が多用されている。図1にワイヤー網目，パル プおよび填料の大きさの関係を示した。何か工夫をし ないと垌料が網目を通過してしまうのは明白である。 この解決の有効な手段がウェットエンド技術である。

製紙における Alumの重要性は依然として大きい が，上記の要因 1) 6) により，これのみでは満足に 機能できなくなった。これを補強あるいは代替するも のとして合成あるいは天然高分子が多く使用されるよ うになった。これらが有効に機能するには，パルプや 填料との適度な相互作用が重要である。相互作用の主 な原動力は静電間力であり, ゼー夕電位など界面動電 現象に関する知識が必要である。最近ではさらに水素 結合力や疎水結合力も注目されるようになった。

高分子薬棛は製紙原料の劣悪化を補う紙力增強剤や $\mathrm{pH}$ の上昇に伴う中性サイズ剤の歩留システムにおい ても重要な役割を演じている。

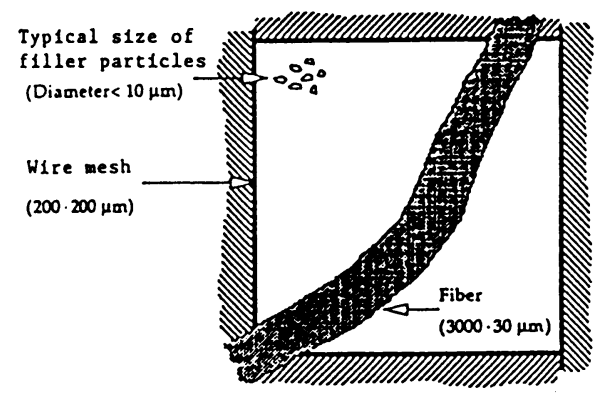

図 1 Size of wire mesh, filler and fiber

\section{2. 界面電気現象 1$) \sim 8$}

\section{1 界面電気の発生}

固液界面は種々の要因で電荷を有している。

\section{1 .1 固体本来の性質に起因するもの}

（1）電離基を有する物質

例えば，パルプはカルボキシル基を有するので，こ れが水中で電離して電荷をもつ。

(2) 粘度鉱物

クレイ $\left(\mathrm{Al}_{2} \mathrm{Si}_{2} \mathrm{O}_{5}(\mathrm{OH})_{4}\right)$ やタルク $\left(\mathrm{Mg}_{3} \mathrm{Si}_{4} \mathrm{O}_{10}\right.$ $\left.(\mathrm{OH})_{2}\right)$ の主成分はケイ酸塩である。鉱物生成過程で $\mathrm{Si}^{4+}$ の一部が他の類似イオン $\left(\mathrm{Al}^{3+} や \mathrm{Mg}^{2+}\right)$ などで 置換され正の原子価が欠けるためマイナスに帯電する。

(3) 酸 化 物

シリカ，アルミナ， $\mathrm{TiO}_{2}$ などの酸化物は水中で表 面は水和して水酸基が存在している。 $\mathrm{TiO}_{2}$ は水中で
はマイナスに帯電する。

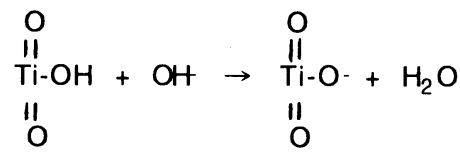

(4) イオン結晶

$\mathrm{CaCO}_{3}$ や $\mathrm{BaSO}_{4}$ などの難溶性塩は水溶液中に構成 イオンが存在すると，これを取り込んで結晶成長しよ うとする (図 2)。

多くの填料はマイナスに带電しているが，沈降性炭 酸カルシュウムは $\mathrm{Ca}^{2+}$ 過利で合成するとプラスに帯 電する。

(液中） $\mathrm{Ca}^{2}+\mathrm{Ca}^{2}+\mathrm{Ca}^{2}+\mathrm{Ca}^{2}+$

（表面）

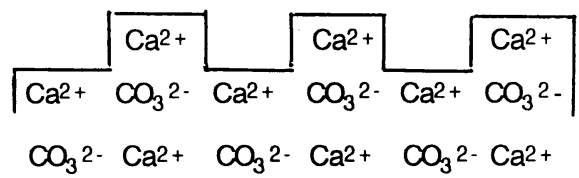

図 $2 \mathrm{CaCO}_{3}$ 粒子表面の $\mathrm{Ca}^{2+}$ 析出による帯電

\section{1 .2 イオンの選択的吸着に起因するもの}

一般に陰イオンは陽イオンより水和しにくく粒子と して小さいので，固体表面の欠陷部に固着しやすい。

\section{2 電気二重層の生成と性質}

水分散系の固体表面は上記の理由でふつうマイナス に帯電している。系全体ではプラスとマイナスのイオ ンは全く等しい（電気的中性の原理）ので，表面の陰 イオンを中和しようとして表面に近い程多くの陽イオ ンが引き付けられる。表面近傍では陽イオンと陰イオ
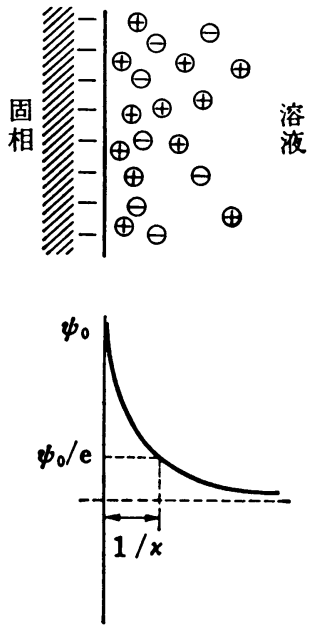

図 3 拡散電気二重層とその厚さ 
表 1 拡散電気二重層の厚さ

\begin{tabular}{c|c|c|c|c|c|c}
\hline 塩類 & 純水 & $\begin{array}{c}\mathrm{NaCl} \\
\left(10^{-3} \mathrm{M}\right)\end{array}$ & $\begin{array}{c}\mathrm{NaCl} \\
\left(10^{-2} \mathrm{M}\right)\end{array}$ & $\begin{array}{c}\mathrm{NaCl} \\
\left(10^{-1} \mathrm{M}\right)\end{array}$ & $\begin{array}{c}\text { Alum } \\
(200 \mathrm{ppm})\end{array}$ & $\begin{array}{c}\text { 平均的白水 } \\
(1=0.01)\end{array}$ \\
\hline 厚さ $(1 / \boldsymbol{x}) \mathrm{nm}$ & 973 & 9.7 & 3.1 & 0.97 & 4.6 & 3.1 \\
\hline
\end{tabular}

ンの濃度が異なって分布することになるが, この状態 を界面電気二重層と呼んでいる（図 3)。電位（中）は 表面から離れるにしたがって減少するが, その様子は (1)式で示すことができる。 $\psi_{0}$ は表面電位, $\mathrm{x}$ は表面 からの距離, $\varkappa$ はイオン強度

$$
\psi=\psi_{0} \exp (-\varkappa x)
$$

の関与するパラメータである。1/火を二重層の厚さと 定義する。(1)式の $\mathrm{x}$ に $1 /$ をを代入すると $\psi(1 / \varkappa)=$

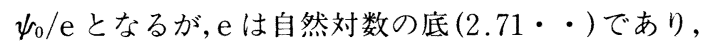
表面電位が $1 / \mathrm{e}$ になる距離が二重層の厚さである（図 3)。

電気二重層の厚さはイオン強度が高い程小さいが, それらの例を表 1 に示す。

なお, 現状では表面電位 $\left(\psi_{0}\right)$ は実測できないので, 代わりにゼー夕電位を測り, 動電現象の指標にしてい る。ゼー夕電位は実測の際, 固液間で実際に起こるず り面の電位である。

\section{3. 原料}

\section{1 パル プ}

製紙の主原料であるパルプの形態, 組織, 成分に関 する知識はウエットエンド技術を有効に利用する上で 重要な要素である。

木材組織, 細胞構造, 微細構造の模式図, 細胞壁の 成分分布，パルプをそれぞれ図 4〜9に示す。

木材の三大成分はセルロース，へミセルロースおよ びリグニンである。パルプの主な荷電はへミセルロー
スの有するカルボキシル基に起因している。

パルプは吒解によって，フィブリル化する（図 9）。

(1) 機械パルプ

木材を磨砕する際にへミセルロースや樹脂酸の一部 が溶出し, また微細成分も生成するので, anionic trash が多い。パルプには大部分のへミセルロースが 残存するので荷電密度が高い。

(2) 末晒し化学パルプ

リグニンの大部分とへミセルロースの相当部分が溶 出する。かなり多孔性となる。

(3) 晒し化学パルプ

漂白とアルカリ抽出を行うので, さらにセルロース 含有率が上がると共に多孔性が進む。

各種パルプの溶質排除法により求められた細孔分布 を図 10 に示す。パルプの荷電密度は樹種や蒸解・漂 白度によってかなり変動するが, 概略值を表 2 に示し た。

晒しパルプの表面積を $200 \mathrm{~m}^{2}$, また荷電（カルボ キシル基）は等間隔で分布すると仮定すると, 荷電密 度 $41 \mu \mathrm{eq} / \mathrm{g}$ の場合, 荷電間距離は $2.8 \mathrm{~nm}$ となる。

\section{2 塡料}

塡料は紙の地合, 白色度, 不透明度, 平滑度, 印刷 適性, 寸法安定性, コスト減を計るために使用されて いる。主な填料は $\mathrm{TiO}_{2}$, カオリン, タルク, $\mathrm{CaCO}_{3}$, 有機フィラーである。

$\mathrm{TiO}_{2}$ の粒径は $0.2 \sim 0.4 \mu \mathrm{m}$, 屈折率は 2.55 (アナ ターゼ), 2.76 (ルチル) であるが, その他は粒径

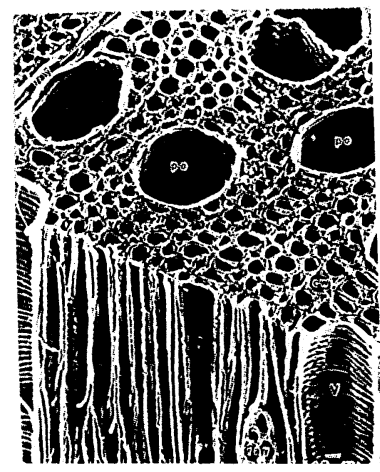

図 4 広葉樹の電子顕微鏡 写真

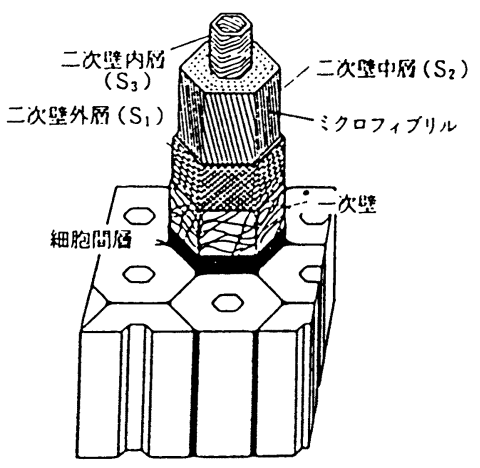

図 5 木材細胞構造

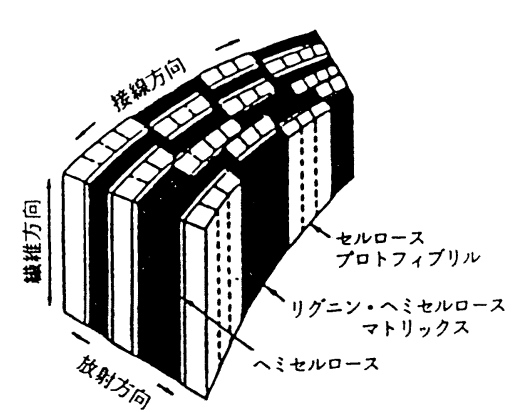

図 6 木質成分の微細配列構造 


田中浩雄

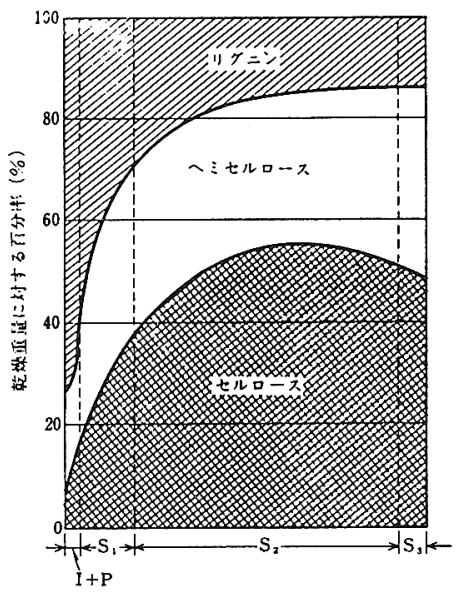

図 7 細胞壁中の主化学成分分布 (a)

(b)

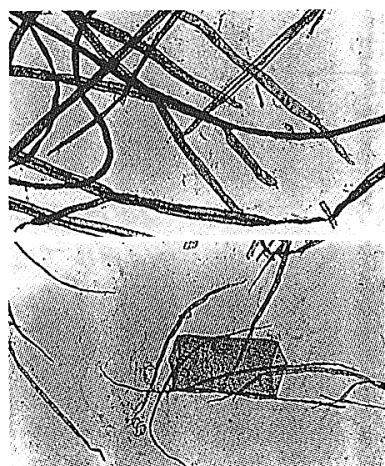

(a) 針葉樹 (b) 広葉樹

図 8 化学パルプ8) (a)

(b)
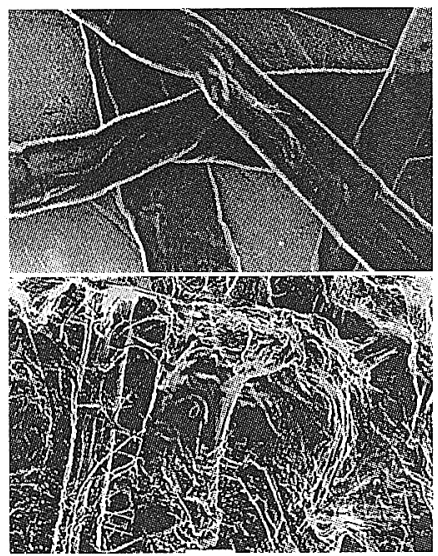

図 9 末吒解および吒解パル $7^{\circ 8)}$

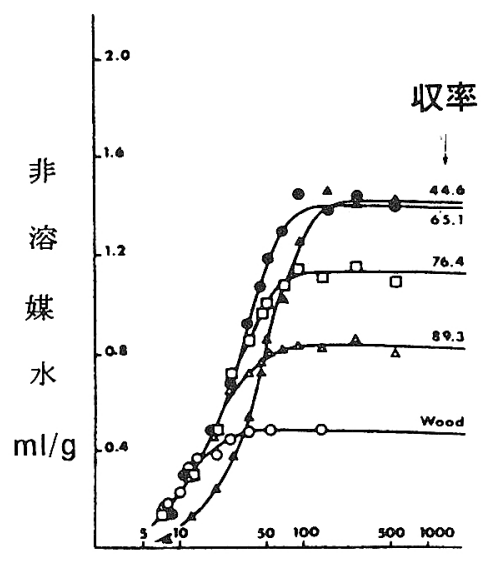

細孔径、 $\AA$

図 $10 \mathrm{KP}$ の溶質排除曲線

表 2 パルプ荷電密度の概略値

\begin{tabular}{c|c|c|c}
\hline & MP & UKP & BKP \\
\hline$\mu \mathrm{eq} / \mathrm{g}$ & $100-150$ & $50-80$ & $30-60$ \\
\hline
\end{tabular}

\section{$0.5 \sim 3 \mu \mathrm{m}$ ，屈折率 1.6 前後である。}

$\mathrm{CaCO}_{3}$ の分散液は微アルカリ性では，遊離の $\mathrm{Ca}^{2+}$ が存在するので，粒子はこれを取り込みゼータ電位は プラスになる（図 2，11）。他の塡料はマイナスのゼ 一夕電位を持つ。しかし，これは平均值であり，粒子 にはプラスとマイナスの部分があることに注意すべき である。

なお，タルクの表面は疎水性が大で，ピッチを良く 吸着する。

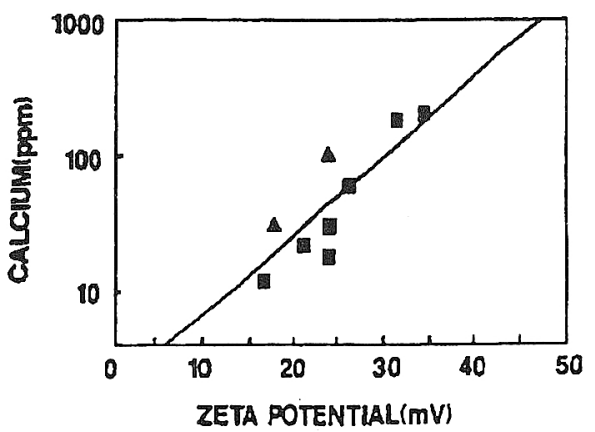

図 11 沈降性 $\mathrm{CaCO}_{3}$ のゼー夕電位と遊離 $\mathrm{Ca}^{2+}$ 濃度 の関係 ${ }^{7)}$

\section{3 ウェットエンドで用いられる薬鼡}

Alum, サイズ郕, 滤水・歩留向上剤, 乾燥紙力増 強剂, 湿潤紙力増強剤, 分散剤, スライムコントロー ル剤がある。それぞれ詳細は以下の章で述べられるで あろう。ここでは同じカテゴリーに属する薬剈でも調 製法によって内容が異なることを示すためにアクリル アミド系ポリマーについて述べる。

アニオン性ポリアクリルアミド（A-PAM）は $\mathrm{PAM}$ の加水分解または $\mathrm{AM}$ とア (メタ) クリル酸 との共重合によって合成されている。カルボキシル基 の分布は前者では均一であるが，後者では不均一であ る。

カチオン性 PAM (C-PAM) はマンニッヒ反応， ホフマン反応またはカチオン性モノマーとの共重合に よって造られている。カチオン基の分布は前二者では 均一となるが，共重合では不均一である。例之ば，下 式の共重合を $\mathrm{QDM} ： \mathrm{AM}=1 ： 9$ （モル比）の仕込み 


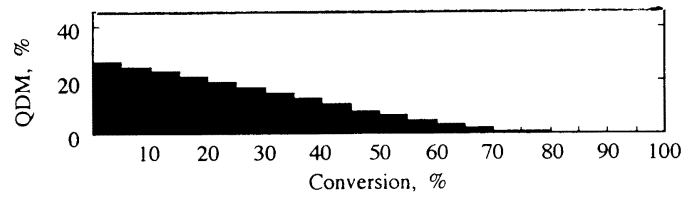

図 12 The change of QDM in C-PAM (polymer $\mathrm{H}$ ) with the conversion of copolymerization.

Notes: $\mathrm{QDM}: \mathrm{AM}=0.1: 0.9(\mathrm{~mol} \%)$. Legend : $\mathbf{\square}=\mathrm{QDM}$

で行った場合，平均のカチオン化度は当然 0.1 である。 しかし，QDMの反応性は AMのそれより高いので, 重合初期にQDM が優先的に反応し, カチオン化度は 0.3 程度になる。重合率が 70\%を越えるとポリマーは 実質的にカチオン性を消失する（図 12）。

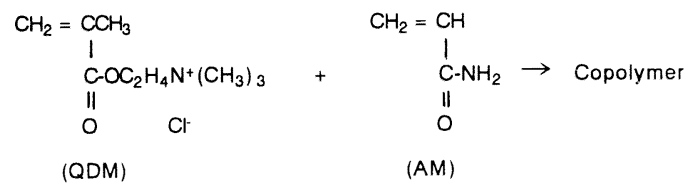

\section{4. 固体表面におけるポリマー吸着の動力学}

いずれの薬剤もそれが機能するには，先ずパルプな どの表面に吸着しなければならない。また，実際の抄 造では, 紙料は薬剤を添加された後 30 秒 2 分程度 でワイヤーパートに達する。一方, 白水中の微細繊維 や媜料は薬郕を付着させたまま長時間循環している。 さらに，製紙工程はポンプによる擋汼や移送など動的 であることも重要な因子である。

薬剤が原料に添加されて以降どのような挙動を取る のか，C-PAM を例として説明しよう。

\section{1 ポリマーの吸着速度}

Falk ら ${ }^{9}$ はパイプにパルプ縣濁液を一定速度で流 しパイプの途中から蛍光ラベルしたカチオン性ポリア クリルアミド (C-PAM) を注入した。抽出する場所 を変えてパルプとポリマーの接触時間を変化させた。 パルプ $1 \mathrm{~g}$ に対し $400 \mu \mathrm{g}$ のポリマーが 0.5 秒後には すでに吸着し，これは数秒間は一定であった（図 13）。 吸着はきわめて迅速に起こることが多くの研究で知ら れている。

\section{1 .1 吸着速度とポリマーの分子量}

ポリマーは一般に広い分子量分布を有している。例 えば，分子量が50万であってもこれは 1 万〜千万の 平均値である。静的条件ではポリマーの吸着は拡散律 速であるから当然分子量の小さいもの程早く起こる。

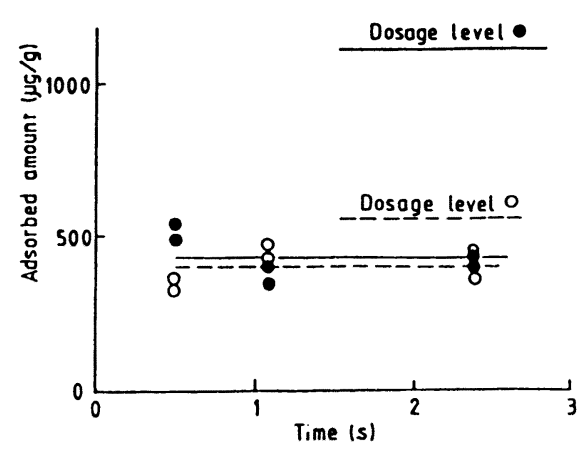

図 13 The adsorption of a fluorescent high molecular weight cationic polyacrylamide at short times. Dosage $1,100 \mu \mathrm{g} / \mathrm{g}$ fibre. $\bigcirc$ Dosage $550 \mu \mathrm{g} / \mathrm{g}$ fibre.

荷電密度 $(0.71 \mathrm{meq} / \mathrm{g})$ は同じであるが, 分子量 は著しく異なるC-PAM を合成した。分子量は $1.1 \times$ $10^{4}$ と $1.7 \times 10^{6}$ で 155 倍の差があった。分析の目的で 前者に僅少の蛍光ラベルを行った。填料のモデルとし て用いた単分散ポリスチレンラテックス (PSL) へ の DDJ $500 \mathrm{rpm}$ 下での吸着結果を図 $14 \mathbf{a}$ に示す ${ }^{10) 。 ~}$

分子量の小さい方が僅かに吸着量は多いが, これは PSL 表面に存在する小さい凸凹のためである。パル プに関する結果を図 $14 \mathbf{b}$ に示した。時間 0 への外扱 値に分子量の差は認められなかった。時間とともに吸 着量が増すのは細孔への進入のためで, これは後で再 度論じる。動的条件では吸着速度に及ぼす分子量の影 響はないことが分かった。

\section{1 .2 吸着速度とポリマーの荷電密度}

前述のように, 共重合体では両モノマーの反応性が 異なるので荷電基の分布が不均一になる。

分子量は近似しているが, 荷電基密度の約 5 倍異な る二種の C-PAM を用いた結果を図 $15 \mathbf{a}, \mathbf{b}$ に示す。 動的な条件下 (DDJ：500 rpm) では分子量と同様に 吸着速度に及ぼす荷電基密度の影響は無視できるほど 小さいことが分かった。

\section{1 .3 紙料とポリマーの衝突頻度}

静的な条件であれば, 衝突頻度は高分子の拡散速度 に支配されるから，例えばパルプ濃度 $0.5 \%$, ポリマ 一濃度 $0.001 \%$ （対パルプ $0.2 \%$ ）であれば吸着には 時間のオーダの長さを要する。しかし, 抄紙系は動的 な条件である。

Saffmann と Turner ${ }^{11)}$ は衝突因子に関し, 次の理 論式を提案している。

$$
\mathrm{N}_{12}=1.294\left(\mathrm{a}_{1}+\mathrm{a}_{2}\right)^{3} \cdot \mathrm{G} \cdot \mathrm{n}_{1} \mathrm{n}_{2}
$$

$\mathrm{N}_{12}$ : 粒子 1 と粒子 2 との衝突頻度 

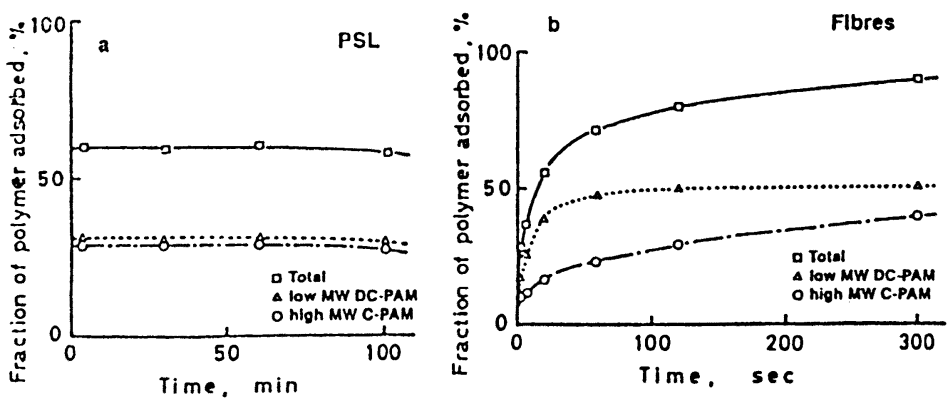

図 14 Competitive adsorption of mixed polymers (high MW CPAM and low MW DC-PAM) onto (a) polystyrene latex particles (PSL) and (b) cellulosic fibres from a bleached kraft pulp. PSL $5.0 \mathrm{~g} / l$, fibres $5.0 \mathrm{~g} / l$, polymer $0.025 \mathrm{~g} / l$ (C-PAM $0.0125 \mathrm{~g} / l$, DC-PAM $0.0125 \mathrm{~g} / l ; 0.5 \%$ on PSL, $0.5 \%$ on fibers), $500 \mathrm{rpm}$. $\square=$ from polyelectrolyte titration; $\triangle$ =from fluorescence intensity; $\bigcirc=\square-\triangle$. Note : Fig. $14 \mathrm{a}$, time in min; Fig.14 b. time in sec.
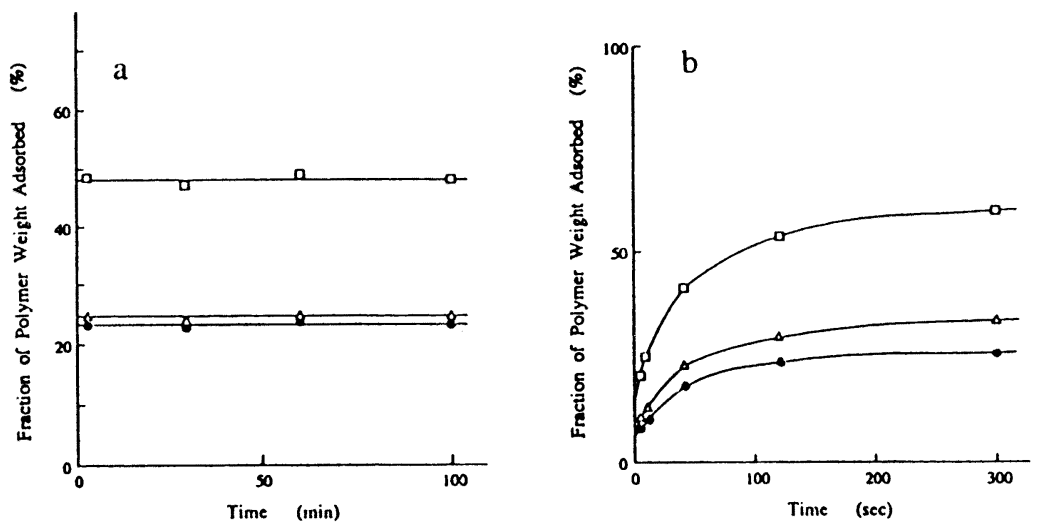

図 15 Competitive adsorption of mixed polymers (high $\mathrm{CD}=\mathrm{DC}$ $\mathrm{PAM} ; 2.9 \mathrm{meq} / \mathrm{g}$ and low $\mathrm{CD}=\mathrm{C}-\mathrm{PAM} ; 0.62 \mathrm{meq} / \mathrm{g}$, but same MWs $; 3.9 \times 10^{5}$ ) onto (a) PSL and (b) cellulosic fibres from bleached kraft pulp. PSL $5.0 \mathrm{~g} / l$, fibres $5.0 \mathrm{~g} / l$, polymer 0.022 $\mathrm{g} / l$ (DC-PAM $0.004 \mathrm{~g} / l$, C-PAM $0.018 \mathrm{~g} / l ; 0.44 \%$ on fibers), $500 \mathrm{rpm} . \square=$ from polyelectrolyte titration; $\mathbf{O}=$ from fluorescence intensity; $\triangle=\square-\mathbf{O}$. Note: Fig.15-a, time in $\min$;

Fig.15-b. time in sec.

$\mathrm{a}_{1}, \mathrm{a}_{2}$ : 粒子 1 および粒子 2 の半径

$\mathrm{G}:$ 水力学的剪断速度

$\mathrm{n}_{1}, \mathrm{n}_{2}$ : 粒子 1 および粒子 2 の個数

(計算例)

パルプ : $5 \mathrm{~kg} / \mathrm{m}^{3}\left(5 \times 10^{10}\right.$ fibers $/ \mathrm{m}^{3}$; equivalent radius $60 \mu \mathrm{m}$ )

$$
\begin{gathered}
\text { ポリマー }: 1 \mathrm{~g} / \mathrm{m}^{3} \text { (対パルプ } 0.02 \% ; 1 \times 10^{17} \\
\text { molecules } \left./ \mathrm{m}^{3} ; \text { radius } 0.1 \mu \mathrm{m}\right) \\
\mathrm{G} \quad: 500 \mathrm{~S}^{-1}(\text { ポリマーの添加場所の } \mathrm{G} は 100 \\
\left.\sim 1,000 \mathrm{~S}^{-1}\right)
\end{gathered}
$$

これらの数值を上式に代入すると, $\mathrm{N}_{12}=7 \times 10^{17}$ collisions $/ \mathrm{m}^{3} \cdot \mathrm{s}$ の結果が得られる。ポリマー数が 1 
$\times 10^{17}$ であるのに対し， 1 秒間の衝突回数が $7 \times 10^{17}$ であるから，単純に計算すると 0.14 秒に 1 回の衝突 が起こることになる。抄紙系におけるパルプとポリマ 一の衝突は極めて高い頻度で起こることが分かる。

ただし，水には粘性があるので，水素結合や柾水結 合のような弱い相互作用の場合, 衝突しても吸着が起 こるかどうかはさらに検討を要する。

\section{2 紙料表面におけるポリマーの}

\section{コンフォメーション変化}

ポリマーは一般に緩い系述状で溶解している。吸着 の瞬間はこの状態であるが, 次第に固体表面へ接触す る部分が増して扁平状へと変化し，平衡に達する。平 衡に達するまでの間に他の表面と結合して凝集を起こ す。また，抄紙系は動的であるから，剪断力によって 凝集塊が破壊される時, ポリマーの転移や主鎖の切断 が起こる。また小さい分子ほど緘維細孔へ進入しやす い。これらの諸現象がどのような時間のオーダでどの くらい起こるかを知ることは, 薬品の添加場所の選定 に際し, 重要な因子となろう。

図 16,17はWagberg ら ${ }^{12)}$ の結果である。CP の吸 着量をコロイド滴定, 対イオン $(\mathrm{Br})$ をイオン電極

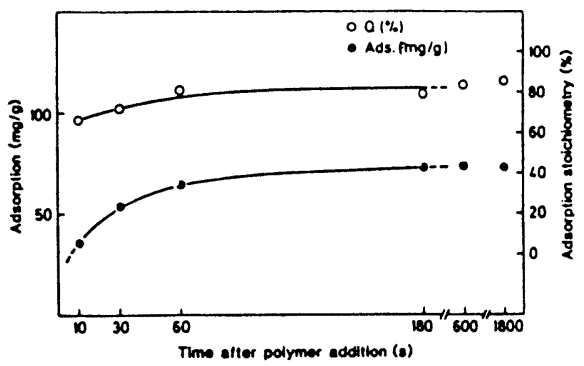

図 16 Kinetics of adsorption and adsorption stoichiometry, Q\%, for the 3,6-ionene on pulps.

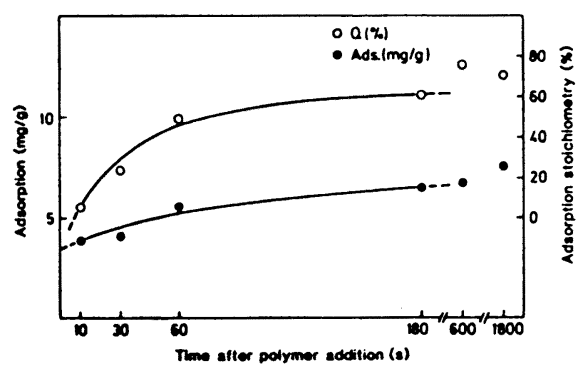

図 17 Kinetics of adsorution and adsorption stoichiometry, Q\%, for the C-PAM on pulps.
Low Charge Density High Adsorption

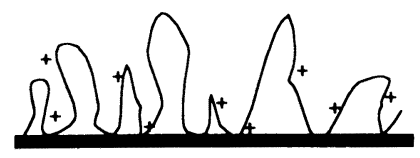

High Charge Density Low Adsorption

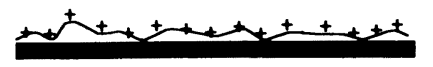

図 18 Pictorial representation of the conformation of adsorbed polyelectrolytes ${ }^{8}$.

で追跡した。荷電密度が高く, 分子量の低い(約 6 千） 3,6-イオネンはごく初期に吸着した CPのアミノ 基のうち $70 \%$ の対イオンが遊離，すなわちパルプに 結合し，その後わずかに増加するのみである。これは 溶液中でも延びて溶解していたポリマーがそのまま扁 平に近い状態で吸着したことを示している（図 16, 18 の下図)。一方, 濾水・歩留り剤として使われてい る分子量 400 万, 荷電密度 $2.6 \mathrm{meq} / \mathrm{g}$ の C-PAM の 結果を図 17 に示す。このC-PAM は水中で緩い系㲑 状を呈している。吸着の初期（10 秒）では，カチオ ン基の約 $5 \%$ がパルプと結合しているのみであるが, その後急速に結合量を増して，1 分後には約 $60 \%$ に達 した。さらにゅっくり増加するが，10 分後も約 $70 \%$ である。かなりのアミノ基がループやテイル部に存在 し，パルプとは結合していないと考えられる（図 18 の上図)。

なお，吸着点の結合は固定されているのではなく， 動的状態にある。これはポリマーの交換反応が起こる ことから証明された ${ }^{13)}$ 。

\section{3 剪断カによる紙料凝集塊の破壊時のポリマー の挙動}

ポリマーの添加により紙料は大なり小なり凝集を起 こすが，ポンプなどによる擋乱を受けると凝集塊の一 部は破壞される。破壊の程度は擋乱の大小とこれを受 ける時間に影響される。へッドボックス中で紙料が層 流化されると再凝集の傾向を示すが，この程度は剪断 の前歴, すなわちポリマーの存在状態によって決まる ものと考えられる。

図19はパルプに吸着したC-PAM と PSLへの転 移の結果である ${ }^{14)}$ 。ポリマー添加 20 秒後に PSL を加 えると転移は急速に起こるが, 20 秒を 2 分, 24 時間 と前吸着時間が長くなるほど転移速度がずっと低くな る。この間にポリマーのコンフォメーション変化と繊 維細孔への進入が起きている。 


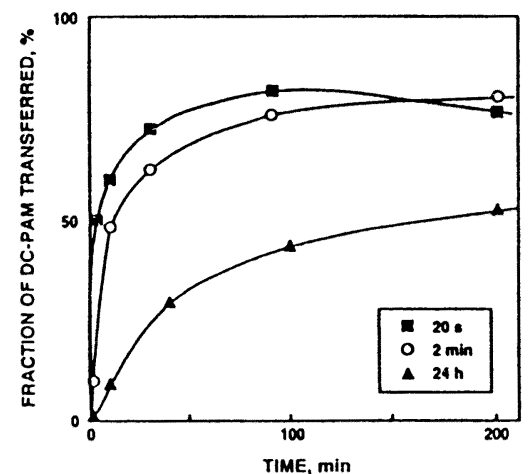

図 19 Transfer of DC-PAM from fibers to PSL particles at three adsorption times for DC-PAM on pulps. $1.0 \%$ pulps, $0.1 \%$ DC-PAM on pulps. $0.5 \%$ PSL, 1,000 $\mathrm{rpm}$

\section{4 転移に伴うポリマー主鎖の切断}

前節の実験で，ポリマーの転移 200 分後に（図 19）, 回収したPSL縣濁液に界面活性剤を添加して吸着し ているポリマーを置換脱着後, 膜で滤別した。このサ イズ排除クロマトグラフィーにより分子量を求めた。

結果を図 20 に示す。転移によって分子量が低下す ることから主鎖が切断されていることが分かる。前吸 着時間が長い程, 吸着ポリマーはパルプ表面で平坦な 形に近づき，すなわちループやテイルの長さが小さく なるので切断数も多くなる。図 20 の例では 8 10 ケ 程度の切断が起こり, 当初の分子量が 500 万でも転移

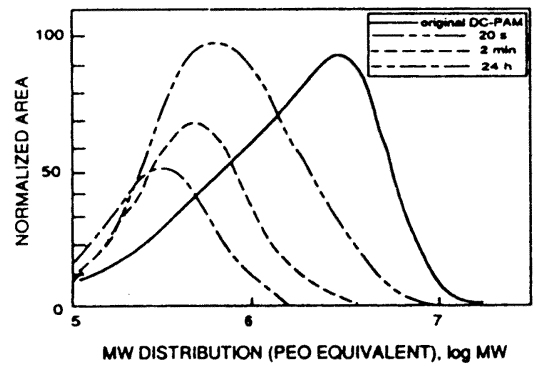

図 20 Molecular weight distribution of DCPAM transferred from fibres to PSL particles at three pre-adsorption times for DC-PAM on fibre. For the experimental conditions, see Fig.19. Below molecular weight $10^{5}$ there is interference from wood polymers leaching from the cellulosic fibres.
後は50～65 万になっている。これが架橋機構による 滤水・歩留りの向上が凝集塊の破壊により不可逆とな ることの一つの理由である。

\section{5 ポリマー瀻維細孔への進入}

PSL およびパルプに対するC-PAM の吸着量の時 間的変化をすでに図 $14 \mathrm{a} ， \mathrm{~b}$ に示した。孔を有しない PSL では吸着量の時間的変化はない。一方，多孔性 のパルプでは時間とともに吸着量は增加してゆく。し かし，この実験は液中に存在する未吸着のポリマーが 時間とともに吸着してゆくことを示すのみで，一旦吸 着したポリーが蝡動運動によって細孔深く進入できる かどうかの判断には役立たない。

この点をポリマー交換反応によって検討した。吸着 したポリマーの固定表面での結合点は固定されている のではなく，切れたり，着いたりの動的平衡にある。 したがって，一旦吸着したポリマーも同種の多量のポ リマーを追加すると一部が交換される。この交換反応 は表面に存在するポリマーほど起こりやすく，細孔内 部に存在するポリマーでは困難である。

C-PAM を合成し ${ }^{15)}$ ，これを二つに分けて，一方に 吸着性が変化しない程度に軽度に蛍光ラベルした (DC-PAM)。蛍光は感度が高いので分析精度は十分 に高かった。まず，PSL またはパルプにDC-PAM を全て吸着する条件で加え，一定時間後に蛍光を有し ないC-PAM を吸着した DC-PAMの 10 倍量加えた。 交換反応が起こり DC-PAM が液中に遊離されるので, 滤液の蛍光が次第に増大する。この結果を図 21,22 に示す ${ }^{16)}$ 。PSLの場合, 前吸着時間が 5 分と 50 分で は交換の程度が少し違うが,これはDC-PAM のコン フォメーション変化によると考えられる。2 時間と 1 週間で变化はない。しかし，パルプでは前吸着時間の

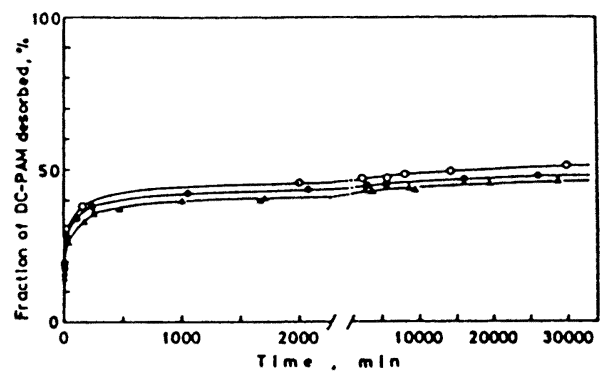

図 21 Effect of time between adsorption and displacement on polystyrene latex. Time between adsorption and displacement: $\bigcirc$ $5 \mathrm{~min},-50 \mathrm{~min}, \triangle 2 \mathrm{hr}, \boldsymbol{\Delta} 1$ week. From Tanaka and Ödberg (1989). 


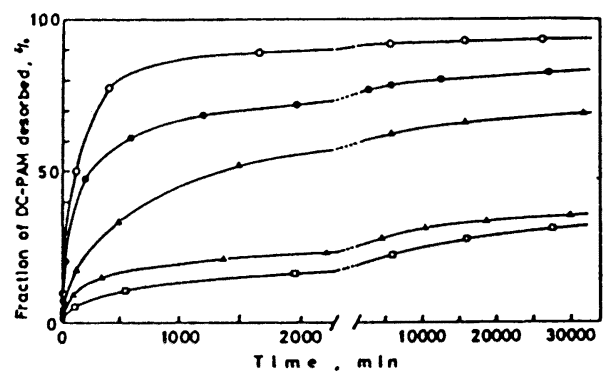

図 22 Effect of time between adsorption and displacement on cellulosic fibres. Time between adsorption and displacement : $\bigcirc$ $5 \mathrm{~min}, \bigcirc 1 \mathrm{hr}, \triangle 15 \mathrm{hr}, \boldsymbol{\Delta} 1$ week, $\square 3$ weeks. From Tanaka and Ödberg (1989).

長さとともに交換され難くなり，これは 3 週間後もな お続いている。すなわち，ポリマーはゆっくりゆっく り細孔へ進入することが出来ることを示している。

パルプ表面ではフィブリルがランダムに配列し，数 十 nmの沢山の網目のあることが原子間力顕微鏡で観 察されている。

\section{6 小 括}

固体表面に㧍けるポリマーの動力学的挙動を要約す ると次のようになる。

吸着：１秒，コンフォメーション变化：～数分, 凝集塊の破壊に伴うポリマーの転移：比較的容易に起 こる, 転移に伴う主鎖の切断：かなり起こる, 細孔へ の進入：一月

これらの挙動はパルプや填料の種類, ポリマーの分 子量・荷電密度, 摚乱の強さ, 用水の質など様々な要 因に影響される。したがって, 操業条件によって歩留 りや滤水性は大きく変動するものと予想される。本稿 で述べた結果は塩が存在しない系で得られたものであ る。実機では当然種々の塩や他の夾雑物が含まれるの で，現象的にはさらに複雑であろう。

\section{PEO-PFR 歩留システムム ${ }^{17) ~ 19) ~}$}

ポリエチレンオキサイド (PEO)ーフェノールホル ムアルデヒド樹脂 (PFR) 凝集システムは初め水処 理に利用されたが, 1980 年頃から新聞抄紙にも応用 されるようになった。新聞抄造系には anionic trash が多く存在し, カチオン性ポリマーはパルプよりこれ らと反応しやすく, 歩留剤として旨く機能しないから である。

PEOは纎維には吸着しないが，PEOのエーテル状
酸素と PFR やクラフトリグニンのフェノール性水酸 基との水素接合を介してネットワークを形成する。こ のネットワークが微細成分を捕集しつつ成長し，パル プのフィブリルなどと結合して歩留まりを向上させる らしい。詳細な機構はまだ不明であるが, 大変興味深 い方法である。

\section{6. 歩留と地合の関係}

製紙の理想は高歩留一良地合であるが，これは二律 背反的な関係にある。歩留まりと地合の関係を定量的 に取り扱った研究はきわめて少ない。大抵の工場で歩 留向上剤が利用されているが，ほとんどは感と経験で 操業されているのが現実であろう。

Albinson ら ${ }^{20)}$ は $\mathrm{CaCO}_{3}$ の歩留まりと地合の関係を Blade former (図 23) のワイヤーテンションを変え て検討した（図 24）。テンションを大きくすると，歩 留まりには影響ないが，地合が改善されたと述べてい る(図 24 中の Formation no.は小さい程地合は良 い)。紙料に対する高い作用力がシートの構成成分を 再配列させ，地合が良くなったと説明している。まだ,

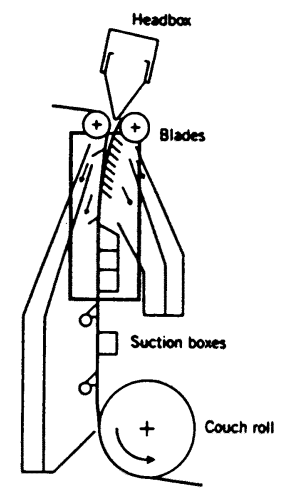

図 23 Blade former

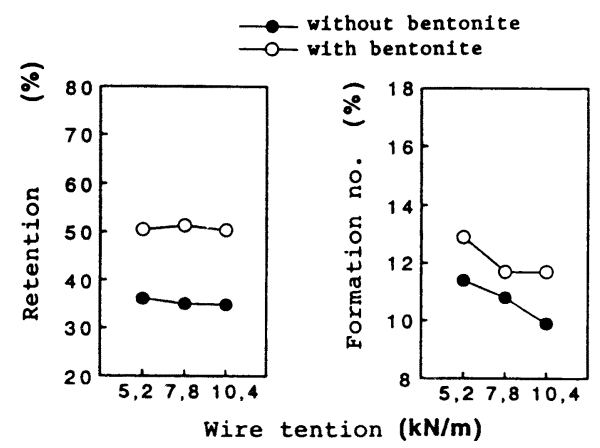

図 24 炭酸カルシュームの歩留りと地合指数に及ぼ す歩留り向上剤とワイヤー張力の影響 


田中浩雄

この分野の研究は遅れているが，マシンの操業条件を 工夫することにより高歩留一良地合の可能性を示し興 味深い。

\section{7.おわりに}

以上, 主としてポリマー吸着の動力学について述べ た。吸着量に及ぼす荷電密度・ $\mathrm{pH}$ ・塩類の影響 ; 架 橋凝集・パッチ型凝結・デュアル・マイクロパーティ クルシステム；乾燥紙力剤・湿潤紙力剤・サイズ剤の 調製や作用機構などについては紙面の都合で割愛した。 これらの多くは以下の章で説明されると思われる。ま た後掲の文献や成書などを参照されたい。

文

1）北原文雄，渡辺昌（編）：「界面電気現象一基礎・ 測定・応用」共立出版, 1972 .

2）山田博：「製紙工程の界面電気現象」紙業夕イム ス, 1979 .

3) Hunter, R. J. : "ZETA POTENTIAL IN COLLOID SCIENCE, Principles and Applications" Academic Press, London, New York, 1981.

北原, 古澤, 尾崎, 大島・「ゼー夕電位, 微粒子 界面の物理化学」サイエンティスト社，1994.

4) Fleer, G. J., Cohen Stuart, M. A., Scheutjens, J. M. H. M., Cosgrove T. and Vincent B.: "Polymers at Interfaces" Chapman \& Hall, London, 1993.

5) Eklund, $\mathrm{D}$ and Lindstrom, $\mathrm{T}$ : "PAPER CHEMISTRY An Introduction" DT PAPER SCI. PUB, Grankulla (Finland), 1991.

6) Roberts, J. C. ed. : "PAPER CHEMISTRY" Blackie, Glasgow, London, 1991.

7) Scott, W. E., : "Principles of Wet End Chemisty" Tappi Press, Atlanta, GA, 1996.

8) Roberts, J. C. : "The Chemistry of Paper" The Royal Soc. Chem., Cambridge, 1996.

9) Falk, M., Odberg, L., Wagberg, L. and Risinger, G. : Colloids Surfaces 40, 115
(1989)

10) Tanaka, H., Swerin A., Odberg, L. and Park, S.-B. : J. Pulp Paper Sci., 23, j 359 (1997)

11) Saffmann, P. G. and Turner, J. S. : J. Fluid Mech. 1,16 (1956).

12) Wagberg, L., Odberg, L., Lindstrom, T. and Aksberg, R. :J. Colloid Interface Sci. 123, 287 (1988).

13) Tanaka, H., Odberg, L., Wagberg, L. and Lindstrom, T. : J. Colloid Interface Sci., 134, 229 (1990).

14) Tanaka, H., Swerin, A. and Odberg, L. : Tappi J.76 (5), 157 (1993) ; Colloid Surfaces A, 86, 201 (1994); Nord. Pulp Paper Res. $J ., 10,261$ (1995) .

15) Tanaka, H. and Odberg, L. : J. Polym. Sci. Chem., 27, 4329 (1989).

16) Tanaka, H. and Odberg, L. : "Fundamentals of Papermaking" Trans. Ninth Fundam. Res. Symp. at Cambridge ed. by C. F. Baker and V. W. Punton, Mech. Eng. Publ. Ltd. London, p. 453 ; Odberg, L., Tanaka, H. and Swerin, A., Nord. Pulp Paper Res. J., 8，6（1993）; 田中浩雄, 山川一秀，紙八゚技協誌 44, 911 (1990)。

17) van de Ven, T. G. M. and Alince, B.: J. Pulp Paper Sci., 22 (7), j 257 (1996).

18) Xiao, H., Pelton, R. and Hamielec, A. : J. Pulp Paper Sci., 22 (12), j 475 (1996); Tappi J., 79 (4), 129 (1996).

19) Swerin, A. and Odberg, L. : "Some aspects of retention aids" in The Fundamentals of Papermaking Materials, Trans. 11 th Fundam. Res. Symp. at Cambridge, 1997.

20) Albinsson, C.-J., Swerin, A. and Odberg, L. : Tappi J., 78 (4), 121 (1995). 